\title{
PROPERTIES OF THIRTEEN KINDS OF ADSORBENTS FOR REMOVAL OF HYDROGEN SULFIDE, METHANETHIOL, METHYL SULFIDE, TRIMETHYLAMINE, AND AMMONIA
}

\author{
Tamotu MIYoshI, ${ }^{\dagger}$ Seiki TANADA ${ }^{\dagger}$ and Keito BoKI ${ }^{\dagger}$ \\ 硫化水素, メチルメルカプタン, 硫化メチル，トリメチルアミン, \\ アンモニアの吸着除去剂とその特性について$$
\text { 三好保*, 棚 田成 紀*, 坊木佳 人* }
$$

\begin{abstract}
Adsorption of hydrogen sulfide, methanethiol, methyl sulfide, trimethylamine, and ammonia on thirteen kinds of adsorbents ( 5 kinds of silicate, 4 kinds of activated carbon, and 4 kinds of zeolite) was measured by gravimetry, at $30^{\circ} \mathrm{C}$ and 50 Torr, using an adsorption apparatus with a spring balance in order to find the most suitable adsorbent for the removal of these gases by dry process. The relations between the amount of these gases adsorbed $\left(\mathrm{mmol} / \mathrm{cm}^{2}\right)$ on the adsorbent and the surface properties or the porous structure were examined to clarify the mechanism of adsorption of these gases on them through surface $\mathrm{pH}$, pore size distribution, and area of an adsorbed particle of these gases.

Among the thirteen adsorbents, the activated carbon Nos. 6 and 7 were the most suitable adsorbent for methanethiol, methyl sulfide, and trimethylamine whose area of an adsorbed particle $\left(w_{\rho}\right)$ was larger than about $17 \AA^{2}$, and zeolite Nos. 12 and 13 were most suitable for removal of hydrogen sulfide and ammonia $\left(w_{\rho}<\right.$ about $\left.17 \AA^{2}\right)$. The amount of these gases adsorbed $\left(\mathrm{mmol} / \mathrm{cm}^{2}\right)$ on these adsorbents was mainly determined by their porous structure rather than by their surface properties.
\end{abstract}

\section{INTRODUCTION}

Hydrogen sulfide, methanethiol, methyl sulfide, trimethylamine, and ammonia are all odorous gases, and are designated as odorous pollutants in our country by the Prime Minister's Office Ordinance ${ }^{1)}$ in 1971. Many reports have been published on the removal of odorous pollutants such as hydrogen sulfide, ${ }^{2-7)}$ methanethiol, ${ }^{6-8)}$ methyl sulfide, ${ }^{9)}$ trimethylamine, ${ }^{7,10)}$ and ammonia ${ }^{11-14)}$ by solid adsorbents.

$\dagger$ Department of Public Health, School of Medicine, Tokushima University

Received for publication, September 6, 1976

* 徳島大学医学部公賉衛生学教室 昭和51年 9 月 6 日受付
The present paper is devoted primarily to the study of fundamental information on the removal of these five kinds of odorous gases by dry process. In order to find the most suitable adsorbent for the removal of each of these gases, equilibrium adsorption on 13 kinds of solid adsorbents was measured by a static adsorption apparatus with a spring balance, at $30^{\circ} \mathrm{C}$ and at pressures up to 50 Torr. The amount of each gas adsorbed per unit surface area, surface $\mathrm{pH}$, and pore size distribution of several adsorbents were measured to clarify the mechanism of adsorption of these gases on the adsorbents (magnesium silicate, activated carbon, and zeolite). The relation between the amount adsorbed per unit surface area $\left(\mathrm{mmol} / \mathrm{cm}^{2}\right)$ of each adsorbent and the area of adsorbed particles $\left(\AA^{2}\right)$ of these gases is discussed. 


\section{EXPERIMENTAL}

\section{Materials}

Hydrogen sulfide, methyl sulfide, and ammonia gases were of certified reagent grade and obtained from Seitetsu Kagaku Company, and their labelled purities were $99.9 \%, 98.0 \%$, and $99.9 \%$, respectively. Methanethiol and trimethylamine gases of 99.07\% purity were obtained from Matheson Gas Products. Solid adsorbents examined in this study are shown in Table 1.

The silicate adsorbents Nos. 1-5 were prepared in our laboratory, and the activated carbon adsorbents Nos. 6-9 and the zeolite adsorbents Nos. 10-13 were commercial products. The particle size of the adsorbents was 4-9 mesh. Their specific surface areas were measured with the Blunauer, Emmett and Teller apparatus using argon gas as an adsorbate at liquid nitrogen temperature $\left(-195^{\circ} \mathrm{C}\right)$.

2. Procedures of adsorption and measurement of the amount adsorbed

The adsorbents were dried at $110^{\circ} \mathrm{C}$ for $1 \mathrm{hr}$ at $1 \times 10^{-4}$ Torr before use. Equilibrium amount of gas adsorbed at $30^{\circ} \mathrm{C}$ and up to 50 Torr was estimated from the streching of a spring balance which became constant after the adsorption took place.

\section{Surface $p H$}

Surface pH values of the adsorbents Nos. 1, 2, 12 , and 13 were obtained using Nishicator (Nishio Universal Indicator; Nishio Kogyo Company). The method of measuring the pH of Nos. 6 and 7 was given previously by Hagiwara et al. ${ }^{15}$ )

\section{Pore size distribution and measurement of integrated pore volume}

The method of measuring the pore size distribution of the adsorbents using methanol as an adsorbate at $3.0^{\circ} \mathrm{C}$ has been given by Urano et al. ${ }^{16)}$ The integrated pore volume of adsorbents was measured by the method of Tanada et al. ${ }^{17)}$

5. Calculation of the area of an adsorbed particle

The numerical value of area of an adsorbed particle on the surface of adsorbents was calculated by using the following equation ${ }^{18)} w_{\rho}=3.464(M / 4$ $\left.\sqrt{2} N_{A} \rho\right)^{2 / 3}$, where $M$ is the molecular weight of the adsorbate, $N_{A}$ the Avogadro number, and $\rho$ the adsorbate density in the liquid state. The derivation of this equation is based on the assumptions concerning the arrangement of molecules in the adsorbed layer (a hexagonal, close packed lattice).

\section{RESULTS AND DISCUSSION}

1. Amount of each gas adsorbed on the adsorbent The amount adsorbed per unit weight of adsorbent is one of the basic parameters required in choosing the most suitable adsorbent for practical purposes and, therefore, the amount of the 5 kinds of gases adsorbed per unit weight on each adsorbent is shown in Table 1. The amount shown in this Table 1 was obtained from the adsorption isotherm and represents the numerical values under the condition of $30^{\circ} \mathrm{C}$ and 50 Torr. Among these adsorbents magnesium silicates Nos. 1 and 2, activated carbon Nos. 6 and 7, and zeolites Nos. 12 and 13 showed the greatest adsorption of those

Table 1. Amount of five kinds of gases adsorbed per unit weight of several adsorbents.

\begin{tabular}{|c|c|c|c|c|c|c|}
\hline \multirow{2}{*}{ No. } & \multirow{2}{*}{ Adsorbent } & \multicolumn{5}{|c|}{ Amount adsorbed (mg/g) } \\
\hline & & $\mathrm{H}_{2} \mathrm{~S}$ & $\mathrm{CH}_{3} \mathrm{SH}$ & $\left(\mathrm{CH}_{3}\right)_{2} \mathrm{~S}$ & $\left(\mathrm{CH}_{3}\right)_{3} \mathrm{~N}$ & $\mathrm{NH}_{3}$ \\
\hline 1 & Magnesium silicate & 23.7 & 76.8 & 123.0 & 103.0 & 68.5 \\
\hline 2 & Magnesium silicate & 21.2 & 66.1 & 116.7 & 102.1 & 56.7 \\
\hline 3 & Aluminium silicate & 4.0 & 0.0 & 20.5 & 9.1 & 7.6 \\
\hline 4 & Calcium silicate & 0.0 & 3.2 & 5.1 & 1.0 & 3.5 \\
\hline 5 & Silica gel & 7.7 & 17.2 & 32.0 & 27.4 & 18.2 \\
\hline 6 & Activated carbon & 42.5 & 200.0 & 237.0 & 207.5 & 7.6 \\
\hline 7 & Activated carbon & 44.1 & 167.5 & 223.2 & 205.0 & 7.8 \\
\hline 8 & Activated carbon & 20.1 & 72.7 & 67.1 & 61.3 & 3.4 \\
\hline 9 & Activated carbon & 32.5 & 109.4 & 89.7 & 78.1 & 4.2 \\
\hline 10 & Synthetic zeolite A-3 & 18.5 & 8.9 & 6.5 & 2.2 & 72.5 \\
\hline 11 & Molecular sieve $5 \mathrm{~A}$ & 76.4 & 31.6 & 38.2 & 32.8 & 73.6 \\
\hline 12 & Synthetic zeolite F-9 & 109.8 & 103.0 & 141.0 & 110.0 & 77.5 \\
\hline 13 & Molecular sieve $13 \mathrm{X}$ & 93.9 & 90.5 & 155.0 & 95.3 & 86.5 \\
\hline
\end{tabular}


Table 2. Amount of five kinds of gases adsorbed per unit surface area of adsorbents.

\begin{tabular}{rlccccr}
\hline \multirow{2}{*}{ No. } & \multirow{2}{*}{ Adsorbent } & \multicolumn{5}{c}{ Amount adsorbed $\left(\mathrm{mmol} / \mathrm{cm}^{2}\right)$} \\
\cline { 3 - 7 } & & $\mathrm{H}_{2} \mathrm{~S}$ & $\mathrm{CH}_{3} \mathrm{SH}$ & $\left(\mathrm{CH}_{3}\right)_{2} \mathrm{~S}$ & $\left(\mathrm{CH}_{3}\right)_{3} \mathrm{~N}$ & $\mathrm{NH}_{3}$ \\
\hline 1 & Magnesium silicate & 16.2 & 37.2 & 46.2 & 40.7 & 93.8 \\
2 & Magnesium silicate & 19.2 & 42.3 & 57.9 & 53.2 & 102.6 \\
6 & Activated carbon & 10.3 & 34.4 & 31.5 & 29.0 & 3.7 \\
7 & Activated carbon & 26.1 & 70.3 & 72.6 & 70.1 & 9.2 \\
12 & Synthetic zeolite F-9 & 61.3 & 40.7 & 43.2 & 35.4 & 86.6 \\
13 & Molecular sieve 13X & 78.1 & 53.3 & 58.0 & 45.7 & 118.2 \\
\hline
\end{tabular}

Table 3. Physical properties of several adsorbents.

\begin{tabular}{rrr}
\hline No. & $\begin{array}{c}\text { Surface area } \\
\left(\mathrm{m}^{2} / \mathrm{g}\right)\end{array}$ & Surface $\mathrm{pH}$ \\
\hline 1 & 428.6 & 6.2 \\
2 & 324.5 & 6.4 \\
6 & 1209.0 & 8.4 \\
7 & 495.0 & 9.9 \\
12 & 525.6 & 8.6 \\
13 & 352.6 & 6.0 \\
\hline
\end{tabular}

gases. The amounts of hydrogen sulfide and ammonia adsorbed on zeolites Nos. 12 and 13 were greater than those on silicates and activated carbon, while the amounts of methanethiol, methyl sulfide, and trimethylamine on activated carbon Nos. 6 and 7 were greater than those on silicates and zeolites. It may be concluded from the amount per unit weight of adsorbent in Table 1 that the most suitable adsorbents for the adsorptive removal of hydrogen sulfide and ammonia are zeolites Nos. 12 and 13, while those for methanethiol, methyl sulfide, and trimethylamine are activated carbon Nos. 6 and 7.

2. Relation between the amount of each gas adsorbed per unit surface area of the adsorbents and their physical properties

One of the purposes of the present study was to clarify the mechanisms of adsorption of 5 kinds of gases on magnesium silicate, activated carbon, and zeolite. The amount adsorbed $\left(\mathrm{mmol} / \mathrm{cm}^{2}\right)$ on several adsorbents are shown in Table 2. These gases used as adsorbates are all polar. It is accordingly conceivable that the amount adsorbed (mmol/ $\mathrm{cm}^{2}$ ) on the adsorbents are determined by their surface properties. Their surface $\mathrm{pH}$ and surface area are shown in Table 3.

It seems that the higher the $\mathrm{pH}$ of the adsorbent, the larger the amount of acidic gas adsorbed on it as compared with the basic gas. However, such a
Table 4. Area of an adsorbed particle of odorous gases.

\begin{tabular}{lllll}
\hline Gas & Area $\left(\AA^{2}\right)$ & & \\
\hline $\mathrm{H}_{2} \mathrm{~S}$ & 16.5 & & & \\
$\mathrm{CH}_{3} \mathrm{SH}$ & 22.4 & & & \\
$\left(\mathrm{CH}_{3}\right)_{2} \mathrm{~S}$ & 26.8 & & & \\
$\left(\mathrm{CH}_{3}\right)_{3} \mathrm{~N}$ & 30.3 & & & \\
$\mathrm{NH}_{3}$ & 12.9, & $11.7,,^{\text {n) }}$ & $14.6,,^{\text {at }}$ & $14.8^{\mathrm{b}}$ \\
\hline
\end{tabular}

a) Kubo, T., Suito, E., Nakagawa, U. and Hayakawa, S. (Eds.): Funtai, Riron to ōyō, 135-136, Maruzen, Tokyo, $1962 . \quad$ b) Hayakawa, S. (Ed.): Funtai busse $i$ sokuteiho, 249, Asakura, Tokyo, 1973.

relation could not be found between the amount adsorbed $\left(\mathrm{mmol} / \mathrm{cm}^{2}\right)$ on the adsorbents (magnesium silicates, activated carbons, and zeolites) in Table 2 and their surface $\mathrm{pH}$ in Table 3. It may be concluded that the amount of 5 kinds of gases adsorbed $\left(\mathrm{mmol} / \mathrm{cm}^{2}\right)$ on magnesium silicates, activated carbon, and zeolites is independent of the surface property such as $\mathrm{pH}$.

Since these gases used as adsorbates have difierent areas for each of adsorbed particle, the relationship between the amount adsorbed $\left(\mathrm{mmol} / \mathrm{cm}^{2}\right)$ on the adsorbents and the area of the adsorbed particle was investigated. Table 4 shows the area of the adsorbed particle of 5 kinds of odorous gases, with a decreasing order of trimethylamine, methyl sulfide, methanethiol, hydrogen sulfide, and ammonia. Generaliy, the larger the area of an adsorbed particle, the smaller the amount adsorbed per unit surface area. Figures 1, 2 and 3 show the area of the adsorbed particle versus the amount adsorbed on magnesium silicates, activated carbon, and zeolites, respectively. There was no linear negative relationship between the number of molecules of each gas adsorbed $\left(\mathrm{mmol} / \mathrm{cm}^{2}\right)$ cn magnesium silicates (Fig.1) as well as on activated carbon (Fig.2) and the 


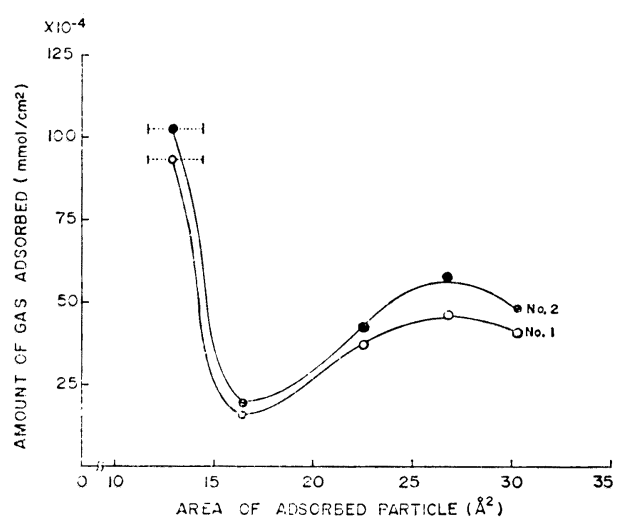

Fig. 1. Area of an adsorbed particle vs. amount of gas adsorbed on magnesium silicates.

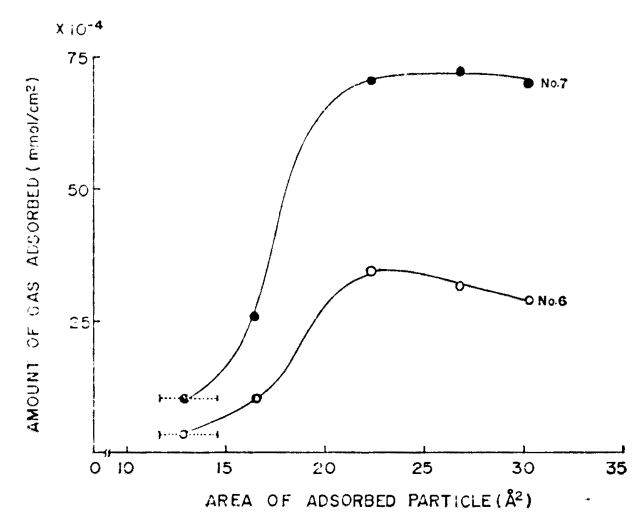

Fig. 2. Area of an adsorbed particle $v s$. amount of gas adsorbed on activated carbon.

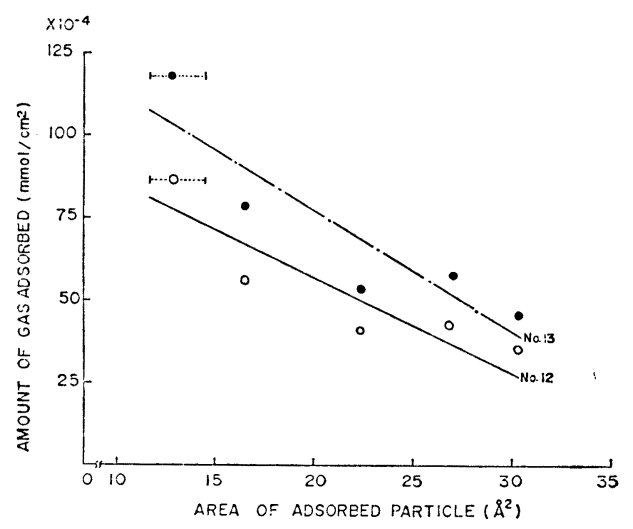

Fig. 3. Area of an adsorbed particic $v s$. amount of ges adsorbed on zeolites.
Table 5. Integrated pore volume above $100 \AA$ in diameter.

\begin{tabular}{cc}
\hline No. & Integrated pore volume $(\mu \mathrm{l} / \mathrm{g})$ \\
\hline 1 & 217.8 \\
2 & 225.4 \\
6 & 590.8 \\
7 & 591.1 \\
12 & 262.2 \\
13 & 230.8 \\
\hline
\end{tabular}

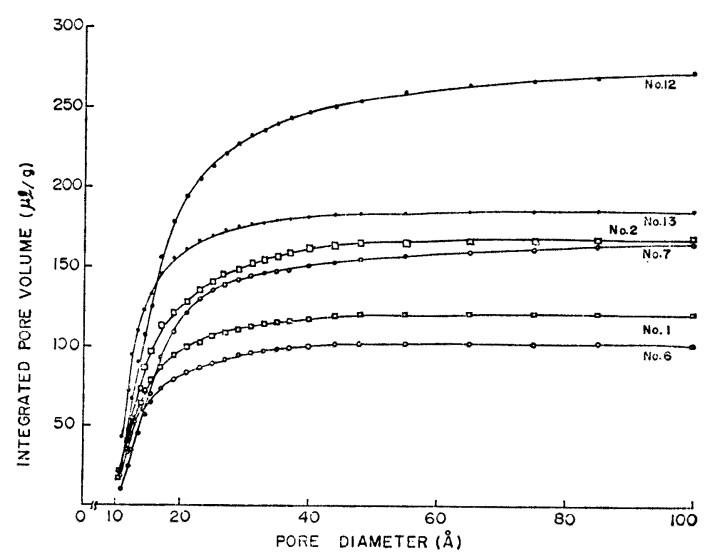

Fig. 4. Pore size distributions of several adsorbents in the range of $10-100 \AA$ in diameter.

area of an adsorbed particle, but the relation in the case of zeolites was roughly linear (Fig. 3). The results in Fig. 1 apparently indicate that the amount adsorbed on magnesium silicates does not always depend on the area of the adsorbed particle. The mechanism of the adsorption on magnesium silicates remains obscure. From Fig. 2 it is clear that the amounts of ammonia and hydrogen sulfide adsorbed on the activated carbon (Nos. 6 and 7) is less than those of methanethiol, methyl sulfide, and trimethylamine. However, the amounts of 5 kinds of gases adsorbed on zeolites (Nos. 12 and 13) in Fig. 3 are contrary to those on the activated carbon as shown in Fig. 2. As the amount of gases adsorbed on the adsorbent relates to its integrated pore volume, the pore size distributions of several adsorbents in the range of 10 to $100 \AA$ in diameter and their integrated pore volume above $100 \AA$ in diameter are shown in Fig. 4 and Table 5, respectively. These five gases are classified into two groups; one having the smaller area of adsorbed 
particle $\left(\mathrm{H}_{2} \mathrm{~S}, \mathrm{NH}_{3}\right)$ and the other having larger area $\left(\mathrm{CH}_{3} \mathrm{SH},\left(\mathrm{CH}_{3}\right)_{2} \mathrm{~S}, \mathrm{~N}\left(\mathrm{CH}_{3}\right)_{3}\right)$.

It is well known that the amount of adsorbate adsorbed on the adsorbent depends on the integrated pore volume of the adsorbent into which the adsorbate can enter. ${ }^{17,19)}$ From the results of the amount adsorbed (Table 2) and integrated pore volume (Fig. 4), it may be considered that the zeolites with larger integrated pore volume than the activated carbon in the range of 10 to $100 \AA$ in diameter have many pores into which ammonia and hydrogen sulfide can enter, but methanethiol, methyl sulfide, and trimethylamine can not. The fact that the amounts of ammonia and hydrogen sulfide adsorbed on the zeolites (Nos. 12 and 13) are larger than those on the activated carbon (Nos. 6 and 7) can be explained by the result that the integrated pore volume of the zeolites is larger than that of the activated carbon in the range of micropore (diameter $<100 \AA$ ) as shown in Fig. 4. While the fact that the amounts of methanethiol, dimethyl sulfide, and trimethylamine adsorbed on the activated carbon are larger than those on the zeolites can be explained by the result that the integrated pore volume of the former is larger than that of the latter in the range above $100 \AA$ in diameter as shown in Table 5.

The results summarized in Tables 1 and 4 show that among the 13 kinds of adsorbents, zeolite Nos. 12 and 13 and magnesium silicate Nos. 1 and 2 were more suitable adsorbents to remove adsorbate gases $\left(\mathrm{NH}_{3}, \mathrm{H}_{2} \mathrm{~S}\right)$ with smaller adsorbed particle area $\left(w_{\rho}<\right.$ about $\left.17 \AA^{2}\right)$, and activated carbon Nos. 6 and 7 were most suitable to remove those $\left(\mathrm{CH}_{3} \mathrm{SH},\left(\mathrm{CH}_{3}\right)_{2} \mathrm{~S}, \mathrm{~N}\left(\mathrm{CH}_{3}\right)_{3}\right)$ with area of adsorbed particle larger than about $17 \AA^{2}$. From this series of experiments, it may be suggested that the amount of these gases adsorbed $\left(\mathrm{mmol} / \mathrm{cm}^{2}\right)$ on activated carbon and zeolites is mainly determined by the porous structure of adsorbents.

\section{REFERENCES}

1) Kato, T.: Taiki Osen no Gaskuromato Gijutsu, (Gas Chromatography of Atomospheric Pollutants), 220, Sankyo Shuppan, Tokyo, 1975.

2) Pollio, F. and Kunin, R.: Macroreticular ion exchange resins as hydrogen sulfide sorbents, Ind. Eng. Chem., 7: 62-65, 1968.

3) Shiio, K.: Mechanism of deodorization of hydrogen sulfide by activated carbon, J. Odor Control, 4: 31-35, 1974.
4) Tanada, S. and Boki, K.: Properties of various adsorbents for removal of hydrogen suifide gas, Chem. Pharm. Bull., 22: 2703-2709, 1974.

5) Boki, K.: Studies on the adsorption removal of hydrogen sulfide gas, Shikoku Acta Medica, 30: 8693, 121-128, 129-134, 276-285, 344-349, 1974.

6) Natusch, D.F.S., Kudson, J.L., Solomon, P.L., Tanner, R. and Miguel, A.: Adsorption of odorous pollutants by active manganese dioxide, PB 234458, $1-36,1974$.

7) Araki, I. and Honda, S.: Catalytic oxidative degradation of odorous components by zeolite catalyzer, Hokkaidôritsu Kogyo Shikenjyo Hokoku, 230: 9-14, 1974.

8) Tanada, S.: Studies on the adsorption removai of methyl mercaptan gas, J. Shikoku Public Health Soc., 19: 57-75, 1974.

9) Suetaka, T.: On adsorptive deodorization method (2), J. Odor Control, 4: 40-44, 1974.

10) Ise, $Y .:$ Studies on the adsorption removal of trimethylamine gas, J. Shikoku Public Health Soc., 19: 76-91, 1974.

11) Matsumura, Y.: Adsorbent of gas protection canister for ammonia, Rôdô Eisei Kenkyusho Nenpô, 49: 75, 1974.

12) Kamata, S. and Tashiro, M.: Gas phase ammonia sorption on macroreticular ion-exchange resin, Kogyo Kagaku Zasshi, 73: 1083-1087, 1970.

13) Torii, K., Asaka, M., Onodera, Y. and Ihara, H.: Adsorption on zeolite tuff, Kogyo Kagaku Zasshi, 74: 2018-2024, 1971.

14) Miyoshi, T., Boki, K. and Tanada, S.: Studies on the adsorption removal of ammonia gas, Jap. J. Ind. Health, 18: 169-176, 1976.

15) Hagiwara, S., Tsutsumi, K. and Takahashi, H.: Interaction between active hydrogen of carbon surface and water, Nippon Kagaku Kaishi, 1369-1373, 1973.

16) Urano, K., Mizusawa, $H$. and Kiyoura, R.: Determination of pore-size distribution from methanol adsorption isotherms, Kogyo Kagaku Zasshi, 73: 1911-1915, 1970.

17) Tanada, S., Boki, K., Tamura, T., Kyotani, S., Arai, Y. and Matsumoto, K.: Effect of manufacturing temperatures and manufacturing methods on the surface properties of magnesium silicates, Yakuzaigaku, 35: 67-73, 1975.

18) Ponec, V., Knor, Z. and Cerny, S. (Smith, B.A. and Adams (trans.)): Adsorption on solids, 541-542, Butterworth, London, 1974.

19) Kitagawa, H.: Preparation of active carbon from phenol-formaldehyde resin, Nippon Kagaku Kaishi, 1144-1150, 1972. 


\section{和文 要 旨}

硫化水素, メチルメルカプタン, 硫化メチル, トリメ チルアミン，アンモニアを乾式沚によって除去するため の最適な吸着剂を胃いだすため，13種吸福剂（ケイ酸塩 5 種類, 活性荻 4 種煩, ゼオライト 4 種類）を用い, ス プリングバシンスを只借した吸着装浑によって重量法に 上り， $30^{\circ} \mathrm{C}, 50$ Torr の条件下で吸着笑験を行なった。 さらに，これらの四疗剂に刘するそれぞれのガスの吸着 機模を究明する几的で, 吸着量と表面極性あるいは細孔
構造との関係について, 表面 $\mathrm{pH}$, 細孔分布曲線, ガス の分子断面積の結果に基づいて検討した.

分子断面積が $17 \AA^{2}$ より大きなメチルメルカプタン, 硫化メチル,トリメチルアミンに最適な吸着剤は, 13 種 吸着剤の中で, 活性炭 No. 6, No. 7 であった. 一方, $17 \AA^{2}$ より小さな硫化水素とアンモニアにはゼオライト No. 12 , No. 13 が最適な吸着剂であった. それぞれの吸 着剂に対するこれらのガス吸着量 $\left(\mathrm{mmol} / \mathrm{cm}^{2}\right)$ は吸着 剤の表面極性よりもむしろ細孔構造によって支配される ことが判明した。

著者への通信先: 三好 保, テ770 德品市蔵本町 3 丁目 18-15 徳島大学医学部公衆衛生学教室 Reprint requests to Department of Public Health, School of Medicine, Tokushima University, 18-15, Kuramotocho 3-chome, Tokushima-shi, 770 Japan (T. Miyoshi) 